\title{
PENGARUH PEMBIAYAAN MUDHARABAH DAN PEMBIAYAAN MUSYARAKAH TERHADAP LABA BERSIH BANK UMUM SYARIAH TAHUN 2014-2017
}

\author{
Imarotus Suaidah \\ Universitas Islam Kadiri \\ imarotussuaidah@gmail.com
}

\begin{abstract}
The purpose of the study is to : 1) analyze the effect of mudharabah financing on net income in syariah commercial bank in 2014-2017. 2) analyze the effect of musyarakah financing on net income in syariah commercial bank in 2014-2017. 3) analyze the effect of mudharabah financing and musyarakah financing on net income in syariah commercial bank in 2014-2017. The benefits of this research is 1) this research can provide knowledge on the effect of mudharabah financing and musyarakah financing on net income at syariah commercial banks. 2) can provide an overview for Islamic banking regarding financing that can increase the net income of syariah islamic banks. 3) for investors, this research can be used as consideration in decision making for their investment.

This study is quantitative descriptive research. The population in this study are syariah commercial bank in Indonesia which is included in the Indonesian Stock Exchange in 2014-2017. The data analysis technique used is mutiple linear regression analysis which previously carried out analysis prerequisite tests.

The results showed that 1) mudharabah financing has influence on net income in syariah commercial bank in 2014-2017. 2) musyarakah financing has influence on net income in syariah commercial bank in 2014-2017. 3) mudharabah financing and musyarakah financing has influence on net income in syariah commercial bank in 2014-2017.
\end{abstract}

Keywords: Mudharabah Financing, Musyarakah Financing, and Net Income.

\section{PENDAHULUAN}

Praktik perbankan berbasis syariah sudah dimulai sejak jaman Rasulullah S.A.W., hanya saja kegiatan perbankan syariah sebatas titipan dan peminjaman harta yang dilakukan sesuai dengan ketentuan dari syariah islam. Perkembangan perbankan syariah berkembang dengan ditandai banyak beredar mata uang yang bisa membedakan dengan mata uang yang lainnya yang dimulai pada jaman bani Abbasiyah. Pada perbankan syariah modern berkembang yang dinamakan dengan bagi hasil antara peminjam dana yakni pihak bank dengan pemakai dana yakni nasabah bank sebagai modal usaha mereka. Menurut Rivai dan Ismal (2013:39) sistem perbankan syariah telah membuktikan dirinya sebagai suatu sistem yang tangguh melalui krisis ekonomi di Indonesia.

Bank syariah pertama kali yang ada di Indonesia adalah Bank Muamalat Indonesia yang merupakan hasil kerja tim perbankan majelis ulama Indonesia (MUI) pada tahun 1991. Landasan hukum Bank Muamalat Indonesia berdasarkan sistem syariah islam yang diaplikasikan di perbankan, seperti tidak adanya sistem bunga dan diganti dengan sistem bagi hasil atau lebih dikenal dengan Profit/Loss Sharing (PLS). sistem bagi hasil berbeda dengan sistem bunga yang dilaksanakan di bank-bank konvensional. Pada sistem keuntungan bagi hasil, besar kecilnya bagi hasil didasarkan pada jumlah keuntungan yang diperoleh. Sedangkan pada sistem bunga, besarnya presentase didasarkan pada jumlah modal yang dipinjamkan. Seperti halnya bank secara umum, bank syariah mengeluarkan produk-produk 
perbankan yang berdasarkan syariah islam. Jika pada bank konvensional menggunakan sistem bunga dalam produk perbankannya, maka lain halnya dengan bank syariah yang menggunakan prinsip keuntungan bagi hasil dalam produk perbankannya. Beberapa produk kegiatan pembiayaan perbankan syariah adalah pembiayaan musyarakah dan pembiayaan mudharabah. Pembiayaan mudharabah merupakan pembiayaan yang digunakan antara dua atau lebih pihak dimana pemilik modal (shahibul mall) memberikan sejumlah modalnya kepada pengguna modal (mudharib) dengan suatu perjanjian. Manfaat dari pembiayaan mudharabah salah satunya adalah bank syariah juga ikut menikmati adanya bagi hasil pada saat keuntungan usaha. Tidak hanya manfaat untuk bank tetapi juga manfaat bagi pengelola modal selaku mudharib yakni pengembalian pokok pembiayaan yang disesuaikan dengan arus kas pengelola modal sehingga tidak membebankan nasabah dalam mengembalikan pokok pembiayaan.

Pendapat Muhammad (2011:260) mengatakan bahwa pembiayaan merupakan fungsi bank dalam menjalankan fungsi penggunaan dana. Tingkat penghasilan dari pembiayaan (yield on financing) adalah penghasilan tertinggi bagi bank. Sama seperti bank-bank konvensional, bank syariah juga tidak bisa menghindari risiko pembiayaan dalam menyalurkan dananya. Hal ini dapat terjadi ketika bank tidak bisa memperoleh kembali pembiayaan yang telah disalurkan atau investasi yang dilakukannya sehingga risiko pembiayaan ini dapat mempengaruhi laba bersih bank syariah. Berdasarkan uraian yang telah diuraikan, peneliti tertarik untuk meneliti "Pengaruh Pembiayaan Mudharabah dan Pembiayaan Musyarakah terhadap Laba Bersih Bank Umum Syariah Tahun 2014-2017".

\section{Batasan Penelitian}

Agar penelitian terfokus dan pembahasan penelitian tidak melebar, maka diperlukan adanya batasan penelitian. Batasan masalah pada penelitian ini terletak pada objek penelitiannya. Objek penelitian yang diteliti adalah bank umum syariah yang terdaftar di Bursa Efek Indonesia selama tahun 2014-2017 dan laporan keuangan tahunan Bank Umum Syariah diterbitkan secara lengkap selama periode 2014-2017.

\section{Rumusan Masalah Penelitian}

Permasalahan yang akan diteliti pada penelitian ini adalah:

a. Bagaimanakah pengaruh pembiayaan mudharabah terhadap laba bersih bank umum syariah tahun 2014-2017?

b. Bagaimanakah pengaruh pembiayaan musyarakah terhadap laba bersih bank umum syariah tahun 2014-2017?

c. Bagaimanakah pengaruh pembiayaan mudharabah dan pembiayaan musyarakah terhadap laba bersih bank umum syariah tahun 2014-2017?

\section{Tujuan Penelitian}

a. Untuk menganalisis pengaruh pembiayaan mudharabah terhadap laba bersih bank umum syariah tahun 2014-2017.

b. Untuk menganalisis pengaruh pembiayaan musyarakah terhadap laba bersih bank umum syariah tahun 2014-2017.

c. Untuk menganalisis pengaruh pembiayaan mudharabah dan pembiayaan musyarakah terhadap laba bersih bank umum syariah tahun 2014-2017. 


\section{Manfaat Penelitian}

a. Penelitian ini dapat memberikan pengetahuan bagaimana pengaruh pembiayaan mudharabah dan pembiayaan musyarakah terhadap laba bersih pada bank umum syariah.

b. Penelitian ini dapat memberikan gambaran bagi perbankan syariah mengenai pembiayaan yang dapat meningkatkan laba bersih bank syariah.

c. Bagi investor, penelitian ini bisa dijadikan bahan pertimbangan dalam pengambilan keputusan.

\section{KAJIAN PUSTAKA}

Menurut Prides(2008:4), bank syariah merupakan bank yang mempunyai produk perbankan berdasarkan pada ketentuan syariah islam. Prinsip syariah itu sendiri merupakan prinsip hukum islam. Jadi bank syariah adalah bank yang mempunyai produk perbankan berdasarkan prinsip hukum islam. Menurut Muhammad (2011:260) secara luas pembiayaan berarti "financing" atau pembelanjaan yang berarti kas yang dikeluarkan untuk melakukan investasi yang telah direncanakan. Sedangkan dalam arti sempit, pembiayaan diartikan sebagai pengeluaran kas yang dilakukan oleh lembaga keuangan, seperti bank syariah kepada klien.

Menurut Antonio (2011:95) mudharabah adalah akad kerja sama diantara dua pihak dimana pihak yang pertama bersedia memberikan seluruh modal kepada pihak kedua, sedangkan pihak kedua mengelola modal yang diberikan pihak pertama. Laba/rugi usaha dibagi berdasarkan perjanjian yang disetujui kedua pihak. Apabila mengalami kerugian, maka kerugian tersebut ditanggung oleh pemilik modal asal kerugian usaha bukan dari akibat kelalaian pengelola modal. Tetapi apabila kerugian usaha diakibatkan karena adanya kelalaian dari pengelola modal, maka pengelola modal harus bertanggung jawab atas kerugian usaha tersebut. Jenisjenis mudharabah menurut Antonio (2011:97) terbagi menjadi dua jenis:

a. Mudharabah muthlaqah, bentuk kerjasama antara pemilik modal dan pengelola modal yang cakupannya tidak terbatas (oleh jenis usaha, waktu dan daerah bisnis).

b. Mudharabah muqayyadah, bentuk kerjasama antara pemilik modal dan pengelola modal yang cakupannya terbatas (oleh jenis usaha, waktu dan daerah bisnis).

Mudharabah dapat berfungsi sebagai dasar bisnis yang dilakukan dengan menggabungkan dana dan keahlian. Musyarakah dapat digunakan sebagai pembiayaan perdagangan dalam dan luar negeri, pembiayaan proyek langsung atau surat berharga.

Ketentuan secara umum pembiayaan pada akad mudharabah menurut Mardani (2013:218) adalah:

a. Jumlah modal yang diberikan kepada nasabah selaku pihak kedua yang mengelola modal harus diberikan tunai, atau yang dinyatakan nilainya dalam satuan uang.

b. Hasil usaha yang dimodali melalui akad mudharabah dapat dihitung dengan 2 cara, yakni revenue sharing (pembagian hasil) dan keuntungan proyek.

c. Hasil usaha akad mudharabah dibagi sesuai dengan persetujuan yang tertuang didalam akad.

d. Bank mempunyai hak untuk mengawasi pekerjaan atau usaha yan dilakukan oleh nasabah yang diberikan modal berdasarkan akad mudharabah, tetapi tidak berhak untuk ikut campur dalam usaha yang dijalani nasabah.

Ascarya (2012:51) mengatakan bahwa musyarakah adalah kontrak atau perjanjian bagi hasil dimana pemilik dana/modal melakukan kerja sama sebagai mitra usaha kepada pengelola modal dalam investasi usaha baru atau yang sudah berjalan. Mitra usaha pemilik 
modal mempunyai hak untuk ikut serta dalam menajemen perusahaan. Para pihak-pihak yang terkait dapat membagi pekerjaan pengelolaan usaha sesuai dengan kesepakatan dan pihakpihak yang terkait juga dapat meminta gaji/upah untuk tenaga dan keahlian yang mereka curahkan untuk usaha tertentu. Apabila terjadi kerugian, maka kerugian tersebut akan ditanggung bersama secara proporsional sesuai dengan kontribusi modal yang telah diberikan oleh kedua belah pihak. Aplikasi pembiayaan musyarakah dalam perbankan syariah ada dua yakni pada pembiayaan proyek dan modal ventura. Jenis pembiayaan musyarakah ada dua yaitu: syirkah inan dan syirkah Al-Uqud. Prosedur pembiayaan musyarakah sebagai berikut: bank umum syariah memberikan modal sejumlah separu dari total modal yang dibutuhkan pihak pengelola modal. Bank syariah dapat menyertakan modal sesuai porsi yang disepakati dengan nasabah. Untuk pembagian hasil keuntungan, tidak harus dihitung sesuai porsi modal yang ditempatkan, akan tetapi sesuai dengan kesepakatan.

Laba bersih adalah selisih antara pendapatan dengan biaya dan pengurangan lainnya. Meningkatnya pendapatan maka akan mempengaruhi perolehan laba bersih. Laba bersih diperoleh dari laba operasi yang dikurangi biaya operasi dan pajak. Kasmir (2010: 309) berpendapat manfaat yang diperoleh dari menganalisis laba adalah:

a. Untuk mengetahui naik turunnya harga jual

b. Untuk alat evaluasi manajemen selama satu periode

c. Sebagai bahan referensi dalam menentukan kebijakan di periode mendatang

Sedangkan manfaat laba menurut Yadiati (2010: 92) memiliki dua fungsi, yaitu yang pertama sebagai alat prediksi dimana hasil laba memberikan informasi sebagai alat taksiran kas dalam pembagian deviden dan sebagai alat taksiran kemampuan perusahaan dalam menaksir earning power dan nilai perusahaan di masa mendatang; yang kedua laba sebagai alat pengendali manajemen dimana laba digunakan sebagai tolok ukur bagi manajemen dalam mengukur kinerja manajer atau divisi dari suatu perusahaan.

Menurut Yadiati (2010:92) terdapat beberapa unsur dalam laba bersih, yaitu:

a. Pendapatan, yakni aliran masuk aktiva perusahaan atau penurunan kewajiban yang terjadi dalam suatu periode akuntansi yang berasal dari penjualan barang.

b. Beban, yakni aliran keluar aktiva perusahaan atau kenaikan kewajiban yang terjadi dalam suatu periode akuntansi.

c. Biaya, yaitu kas yang dikorbankan untuk barang atau jasa yang diharapkan membawa keuntungan masa ini dan masa datang.

d. Untung rugi, kenaikan atau penuruna ekuitas yang berasal dari transaksi incindental yang terjadi pada perusahaan dalam suatu periode akuntansi selain yang berasal dari pendapatan investasi pemilik.

e. Penghasilan, hasil akhir penghitungan dari pendapatan dan keuntungan dikurangi beban dan kerugian dalam periode tersebut.

Ada beberapa faktor yang mempengaruhi perubahan laba bersih diantaranya menurut Jumingan (2011:165) adalah: a) naik turunnya jumlah unit yang dijual dan harga jual per unit; b) naik turunnya harga pokok penjualan; c) naik turunnya biaya usaha yang dipengaruhi oleh jumlah unit yang dijual; d) naik turunnya biaya non operasional yang dipengaruhi oleh variasi jumlah unit yang dijual; e) naik turunnya pajak perseroan yang dipengaruhi oleh besar kecilnya laba yang diperoleh atau tinggi rendahnya tarif pajak.

\section{Penelitian terdahulu}

Penelitian yang dilakukan oleh Wibowo dan Sunarto (2015) menjelaskan bahwa terdapat pengaruh pembiaayaan mudharabah dan pembiayaan musyarakah terhadap profitabilitas yang diukur menggunakan ROE. Sedangkan penelitian yang dilakukan oleh Darwis (2016) 
menyatakan bahwa pembiayaan mudharabah berdampak positif pada laba. Penelitian yang dilaksanakan oleh Rosyid dan Nurdina (2015) menjelaskan bahwa pembiayaan mudharabah menunjukkan hasil signifikan terhadap laba bersih pada bank umum syariah.

\section{METODE PENELITIAN}

\section{Populasi dan Sampel Penelitian}

Populasi menurut Sugiyono (2014:61) adalah obyek/subyek yang mempunyai kuantitas dan karakteristik tertentu yang ditetapkan oleh peneliti untuk dipelajari dan kemudian ditarik kesimpulannya. Sedangkan pengertian sampel adalah bagian dari obyek/subyek yang akan diteliti. Populasi dalam penelitian ini adalah bank umum syariah yang terdaftar di Bursa Efek Indonesia selama tahun 2014-2017 sebanyak 12 bank umum syariah, untuk teknik sampling yang digunakan pada penelitian ini adalah teknik sampling purposive, dimana teknik pengambilan sampling ini menggunakan kriteria tertentu. Kriteria yang ditetapkan adalah 1) Bank Umum Syariah yang diteliti adalah Bank Umum Syariah yang terdaftar dalam Bursa Efek Indonesia dan melaporkan laporan keuangannya secara beruntun dan lengkap selama periode 2014-2017.

\section{Data dan Teknik Pengumpulannya}

Sumber data yang digunakan adalah data sekunder. Data sekunder yaitu sumber data penelitian yang diperoleh peneliti melalui pihak kedua atau lembaga lain. Data yang digunakan pada penelitian adalah data sekunder yang berasal dari laporan keuangan (annual report) bank umum syariah selama tahun 2014-2017. Teknik pengumpulan data yang digunakan adalah teknik data dokumentasi.

Variabel dependen pada penelitian ini adalah laba bersih dari bank umum syariah. Sedangkan untuk variabel independen pada penelitian ini adalah pembiayaan mudharabah dan pembiayaan musyarakah pada bank umum syariah.

\section{Teknik Analisis Data}

Alat analisis data yang digunakan adalah analisis regresi linier berganda. Dimana sebelumnya dilakukan uji prasyarat analisis. Uji prasyarat analisis yang digunakan adalah uji normalitas dan uji linieritas.

\section{Uji Prasyarat Analisis \\ Uji Normalitas}

Uji ini menguji apakah data dalam penelitian berdistribusi normal. Uji normalitas dikatakan lolos apabila data yang diuji berdistribusi normal.

Tabel 1

Uji Normalitas

(One-Sample Kolmogorov-Smirnov Test)

\begin{tabular}{|ll|r|r|r|}
\hline & & X1 & \multicolumn{1}{|c|}{ X2 } & \multicolumn{1}{c|}{ Y } \\
\hline & $\mathrm{N}$ & 20 & 20 & 20 \\
Normal & Mean & 744.90 & 7468.30 & 137.95 \\
Parameters & Std. & 621.553 & 7433.94 & 119.02 \\
a,b & Deviation & & 6 & 3 \\
Most & Absolute & .148 & .257 & .184 \\
Extreme & Positive & .148 & .257 & .184 \\
& & &
\end{tabular}




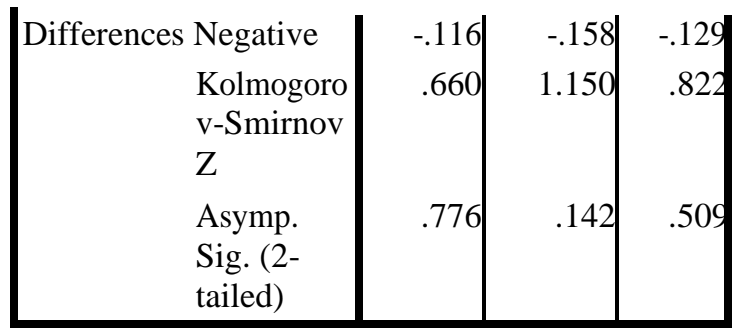

a. Test distribution is Normal.

b. Calculated from data.

Sumber : Hasil Uji SPSS

Hasil dari uji normalitas pada tabel 1.1 dimana untuk variabel pembiayaan mudharabah dengan asymp. Sig. sebesar 0,0776 dimana hasilnya >0,05 yang berarti distribusi data pembiayan mudharabah normal, untuk variabel pembiayaan musyarakah hasil asymp. Sig. sebesar 0,142 dimana hasilnya >0,05 yang berarti data pembiayaan musyarakah berdistribusi normal, sedangkan laba bersih asymp. Sig. sebesar 0,509 >0,05 yang berarti data laba bersih berdistribusi normal.

\section{Uji Linieritas}

Uji ini menurut Ghozali (2016:159) menguji apakah spesifikasi model yang digunakan sudah benar atau tidak. Hasil uji linieritas sebaiknya harus linier. Berdasarkan hasil analisis uji linieritas sebesar 0,748 dengan taraf siginifikansi 0,05. Hasil ini dikatakan linier apabila hasil ujinya lebih besar dari 0,05 . Oleh karena hasil uji linieritas lebih dari 0,05 maka data pembiayaan mudharabah, pembiayaan musyarakah, dan laba bersih linier.

\section{PEMBAHASAN HASIL PENELITIAN \\ Uji Hipotesis \\ Uji t}

Uji t menguji seberapa jauh pengaruh satu variabel independen terhadap variabel dependen. Bila nilai signifikansi $<0,05$ maka variabel independen mempunyai pengaruh terhadap variabel dependen.

Tabel 2

U.ji t

\begin{tabular}{|c|c|c|c|c|c|}
\hline \multirow[b]{2}{*}{ Model } & \multicolumn{2}{|c|}{$\begin{array}{l}\text { Unstandardize } \\
\text { d Coefficients }\end{array}$} & \multirow{2}{*}{$\begin{array}{c}\text { Standardized } \\
\text { Coefficients } \\
\text { Beta }\end{array}$} & \multirow[b]{2}{*}{$\mathrm{t}$} & \multirow[b]{2}{*}{ Sig. } \\
\hline & B & \begin{tabular}{|l|} 
Std. \\
Error
\end{tabular} & & & \\
\hline $\begin{array}{c}1 \text { (Const } \\
\text { ant) }\end{array}$ & $\begin{array}{r}158.98 \\
2\end{array}$ & 49.460 & & 3.214 & .005 \\
\hline $\mathrm{X} 1$ & -.003 & .047 & -.015 & -.062 & .041 \\
\hline $\mathrm{X} 2$ & -.003 & .004 & -.158 & -.648 & .026 \\
\hline
\end{tabular}

a. Dependent Variable: Y

Sumber : Hasil Uji SPSS

Hasil pengujian ditemukan bahwa nilai signifikansi variabel pembiayaan mudharabah sebesar 0,041, dimana hasil uji $\mathrm{t}<0,05$ yang berarti variabel pembiayaan mudharabah berpengaruh terhadap variabel laba bersih pada bank umum syariah. Sedangkan untuk hasil nilai sig. variabel pembiayaan musyarakah sebesar 0,026, dimana hasil uji $\mathrm{t}<$ 
0,05 yang menunjukkan bahwa variabel pembiayaan musyarakah berpengaruh terhadap laba bersih bank umum syariah.

\section{Uji f}

Uji f menguji seberapa jauh pengaruh variabel independen-independen secara simultan terhadap variabel dependen. Bila nilai signifikansi < 0,05 maka variabel independen secara simultan atau bersama-sama memberikan pengaruh kepada variabel dependen.

\section{Tabel 3}

Uji f

ANOVA $^{b}$

\begin{tabular}{|l|r|r|r|r|r|}
\hline Model & $\begin{array}{r}\text { Sum of } \\
\text { Squares }\end{array}$ & df & $\begin{array}{r}\text { Mean } \\
\text { Square }\end{array}$ & F & Sig. \\
\hline $1 \quad$ Regressio & 7011.344 & 2 & 3505.6 & .227 & .000 \\
& & & 72 & & \\
R Residual & 262151.6 & 17 & 15420. & & \\
& 06 & 683 & & \\
Total & 269162.9 & 19 & & & \\
& 50 & & & & \\
\hline
\end{tabular}

a. Predictors: (Constant), X2, X1

b. Dependent Variable: Y

Sumber : Hasil Uji SPSS

Dari hasil analisis uji f ditemukan bahwa nilai sig. sebesar 0,000 dimana hasil ini < 0,05 yang menunjukkan bahwa variabel pembiayaan musyarakah dan pembiayaan musyarakah secara bersama-sama (simultan) berpengaruh pada laba bersih bank umum syariah di Indonesia.

\section{Uji Koefisien Determinasi}

Uji ini mengukur kemampuan variabel independen dalam menjelaskan variabel dependennya. Jika hasil uji ini kecil berarti kemampuan variabel independen dalam menjelaskan variabel dependennya terbatas.

Tabel 4

Uji Koefisien Determinasi Model Summary

\begin{tabular}{|l|c|r|r|r|}
\hline Model & $\mathrm{R}$ & $\begin{array}{c}\mathrm{R} \\
\text { Square }\end{array}$ & $\begin{array}{c}\text { Adjusted R } \\
\text { Square }\end{array}$ & $\begin{array}{c}\text { Std. Error of } \\
\text { the Estimate }\end{array}$ \\
\hline 1 & $.161^{\mathrm{a}}$ & .026 & -.089 & 124.180 \\
\hline
\end{tabular}

a. Predictors: (Constant), X2, X1

Sumber : Hasil Uji SPSS

b. Dependent Variable: Y

Dari uji koefisien determinasi yang dilakukan, didapat hasil uji sebesar 0,026 yang menunjukkan bahwa pembiayaan mudharabah dan pembiayaan musyarakah memiliki kontribusi sebesar 2,6\% dalam mempengaruhi laba bersih bank umum syariah tahun 20142017, sedangkan sisanya sebesar 98\% dipengaruhi oleh variabel selain pembiayaan mudharabah dan pembiayaan musyarakah. 


\section{Pembahasan}

Berdasarkan hasil penelitian, ditemukan bahwa produk perbankan pembiayaan yang diteliti pada bank umum syariah yang ada di Indonesia yakni pembiayaan mudharabah dan pembiayaan musyarakah berpengaruh pada laba bersih bank umum syariah tahun periode 2014-2017. Hasil penelitian menunjukkan bahwa variabel pembiayaan mudharabah dan pembiayaan musyarakah menjelaskan variabel laba bersih sebesar $2 \%$, sedangkan sisanya yakni sebesar $98 \%$ dijelaskan oleh variabel lain diluar variabel penelitian. Hal ini menunjukkan bahwa variabel di luar penelitian selain pembiayaan mudharabah dan pembiayaan musyarakah mempengaruhi sebesar 98\%. Menurut Yudiati (2010:92) terdapat beberapa unsur dalam laba bersih, yaitu: Pendapatan, Beban, Biaya, untung untung rugi dan penghasilan. Pembiayaan mudharabah dan pembiayaan musyarakah termasuk dalam salah satu unsur yang mempengaruhi laba bersih seperti yang dijelaskan oleh Yudiarti.

Penelitian yang dilakukan oleh Wibowo dan Sunarto (2015) mengungkapkan bahwa baik secara parsial maupun simultan pembiayaan mudharabah dan pembiayaan musyarakah berpengaruh terhadap profitabilitas yang diukur menggunakan ROE. Hasil tersebut sesuai dengan penelitian Darwis (2016) yang menyatakan bahwa perlu digalakkannya pembiayaan mudharabah sebagai produk unggulan karena berdampak positif pada laba, begitu pula dengan pembiayaan musyarakah yang berpengaruh secara positif terhadap laba bersih. Hasil serupa diperoleh dari penelitian yang dilakukan Rosyid dan Nurdina (2015) yang menjelaskan bahwa pembiayaan mudharabah menunjukkan hasil signifikan terhadap laba bersih pada bank umum syariah.

\section{PENUTUP}

\section{Kesimpulan}

Setelah pembahasan diatas, maka dapat disimpulkan bahwa:

a. Pembiayaan mudharabah mempunyai pengaruh terhadap laba bersih bank umum syariah selama tahun 2014-2017

b. Pembiayaan musyarakah mempunyai pengaruh terhadap laba bersih bank umum syariah selama tahun 2014-2017

c. Pembiayaan mudharabah dan pembiayaan musyarakah pengaruh terhadap laba bersih bank umum syariah selama tahun 2014-2017

\section{Saran}

Pada penelitian selanjutnya, dapat ditambahkan variabel lain seperti produk perbankan syariah seperti tabungan wadi'ah, pendapatan murabah, atau pembiayaan-pembiayaan syariah lainnya yang dapat meningkatkan laba bersih pada bank umum syariah di Indonesia. 


\section{DAFTAR PUSTAKA}

Alhudri, Sahid. 2018. "Analisis Faktor-Faktor yang Mempengaruhi Laba Perusahaan Asuransi Syariah di Indonesia Periode 2012-2016 (Studi Pada Perusahaan Asuransi Kerugian Syariah di OJK Periode 2012-2016)”. Skripsi tidak dipublikasikan. Jakarta: Jurusan Ekonomi Syariah, Universitas Islam Negeri Syarif Hidayatullah.

Antonio, Muhammad Syafi'I. 2011. Bank Syariah: Dari Teori ke Praktik. Jakarta.Gema Insani.

Ascarya. 2012. Bank dan Produk Bank Syariah. Jakarta. Rajawali Press.

Ayub, Muhammad. 2007. Understanding Islamic Finance A-Z Keuangan Syariah. Jakarta. PT Gramedia Pustaka Utama.

Bank BCA Syariah Indonesia. 2018. Laporan Keuangan Tahunan Bank BCA Syariah Indonesia. Jakarta. Sumber: http:// www.bcasyariah.co.id. Diakses Tanggal 6 Desember 2018.

Bank BNI Syariah Indonesia. 2018. Laporan Keuangan Tahunan Bank BNI Syariah Indonesia. Jakarta. Sumber: http:// www.bnisyariah.co.id. Diakses Tanggal 6 Desember 2018.

Bank Indonesia. 2018. Laporan Keuangan Publikasi Bank Umum Syariah. http://www.bi.go.id. Diakses Tanggal 6 Desember 2018.

Bank Indonesia. 2018. Laporan Keuangan Tahunan. https://www.bi.go.id/id/publikasi/laporan-tahunan/bi/Pages/LKTBI-2016.aspx. Diakses Tanggal 6 Desember 2018.

Bank Mandiri Syariah Indonesia. 2018. Laporan Keuangan Tahunan Bank Mandiri Syariah Indonesia. Jakarta. Sumber: http:// www.syariahmandiri.co.id. Diakses Tanggal 6 Desember 2018.

Bank Muamalat Indonesia. 2018. Laporan Keuangan Tahunan Bank Muamalat Indonesia. Jakarta. Sumber: http:// www.muamalatbank.co.id. Diakses Tanggal 6 Desember 2018. 
Darwis, Muhammad Afif. 2016. "Pengaruh Pembiayaan Mudharabah Dan Musyarakah Terhadap Laba Bersih Melalui Pendapatan Bagi Hasil Pada Bank Syariah Tercatat Di Bursa Efek Indonesia”. Tesis tidak dipublikasikan. Makassar. Jurusan Ekonomi Islam, Universitas Islam Negeri Alauddin Makassar.

Ghozali, Imam. 2016. Aplikasi Analisis Multivariate Dengan Program IBM SPSS 23. Semarang: Badan Penerbit Universitas Diponegoro.

Jumingan. 2011. Analisis Laporan Keuangan. Jakarta. PT Bumi Aksara.

Kasmir. 2010. Analisis Laporan Keuangan. Jakarta. Rajawali Pers.

Mardani. 2013. Fiqh Ekonomi Islam: Fiqh Muamalah.Jakarta. Kencana.

Mardhiyah, Risma Ifatul. 2016. "Analisis Pengaruh Pembiayaan Mudharabah dan Musyarakah terhadap Tingkat Profitabilitas (Return On Equity) Pada Bank Umum Syariah di Indonesia". Artikel Sekolah Tinggi Ilmu Ekonomi Perbanas Surabaya.

Muhammad. 2008. Paradigma, Metodologi\&Aplikasi Ekonomi Syariah. Yogyakarta. Graha Ilmu.

Muhammad. 2011. Manajemen Bank Syariah. Yogyakarta. UPP AMP YKPN BPFE.

Nurhidayah dan Any Isvandiari. 2016. "Faktor Internal dan Faktor Eksternal Yang Mempengaruhi Alokasi Pembiayaan Usaha Kecil Menengah (Studi Pada Bank Syariah indonesia)". Jurnal JIBEKA. Vol. 10, No.1, hlm 42-48. 
Pramudhito, R. Ade Sasongko. 2018. "Analisis Pengaruh CAR, NPF, BOPO, FDR, dan NCOM Terhadap Profitabilitas Bank Umum Syariah (Studi Kasus Pada Bank Umum Syariah di Indonesia PeriodeB 2008-2012)”. Sumber:https://www.academia.edu/23707437/ANALISIS PENGARUH CAR NPF BOPO_FDR_DAN_NCOM_TERHADAP_PROFITABILITAS_BANK_UMUM_SY ARIAH DI INDONESIA. Diakses pada tanggal 6 Desember 2018.

Prides, Tim Manajemen. 2008. Kompilasi Perundang-undangan tentang Ekonomi Syariah. Jakarta. Gaung Persada Press Jakarta.

Rivai, Veithzal dan Rifki Ismail. 2013. Islamic Risk Management For Islamic Bank. Jakarta. PT. Gramedia Pustaka Utama.

Rosyid, Maskur dan Fitria Nurdina. 2015. "Mudharabah dan Murabahah; Pengaruhnya Terhadap Laba Bersih BUS”. Jurnal Islaminomic. Vol. 6, No.2, Hlm. 53-77.

Sari, Silfia Permata. 2018. "Pengaruh Pembiayaan Murabahah, Mudharabah, Ijarah dan Qardh Terhadap Tingkat Laba Bersih Pada Bank Umum Syariah di Indonesia Periode Tahun 2014-2017”. Skripsi tidak dipublikasikan. Jakarta. Jurusan Perbankan Syariah, Universitas Islam Negeri Syarif Hidayatullah.

Sartono, Agus. 2012. Manajemen Keuangan:Teori dan Aplikasi. Edisi Keempat. Yogyakarta. BPFE

Sulistyo. 2011. “Analisis Rasio Keuandaftar gan dalam Memprediksi Laba yang Akan Datang Pada Perusahaan Manufaktur di Bursa Efek Indonesia”. Jurnal Modernisasi. Vol. 7, No.1,Hlmn. 73-92.

Wibowo, Arif dan Sunarto. 2015. "Pengaruh. Pembiayaan Mudharabah Dan Musyarakah Terhadap Profitabilitas Perbankan Syariah (Studi Kasus pada Bank Pembiayaan Rakyat Syariah Daerah Istimewa Yogyakarta yang terdaftar di Bank Indonesia Periode 2012-2014)". Seminar Nasional dan The 3rd Call for Syariah Paper. ISSN 2460-0784. hlm 115-124.

Yadiati, Winwin. 2010. Pengantar Akuntansi. Jakarta. Prenada Media Group. 